\title{
AREA-STORAGE CAPACITY CURVE OF HISTORIC ARTIFICIAL WATER RESERVOIR OTTERGRUND, SLOVAKIA - ASSESSMENT OF THE HISTORICAL DATA WITH THE USE OF GIS TOOLS
}

\author{
Jakub Fuska', Daniel Kubinský², Karol Weis³, Lenka Lackóová4, \\ Jozefína Pokrývková', Mária Leitmanová4 ${ }^{\text {, Thomas Panagopoulos }}{ }^{5}$
}

1 Department of Water resources and Environmental Engineering, Slovak University of Agriculture in Nitra, Hospodárska 7, 94976 Nitra, Slovakia

2 Department of Ecology and Environmental Sciences, Constantine the Philosopher University, Tr. A. Hlinku 1, 94974 , Nitra, Slovakia

${ }^{3}$ Department of Geography and Geology, University of Mathias Bel in Banská Bystrica, Tajovského 40, 974 01, Banská Bystrica, Slovakia

${ }^{4}$ Department of Landscape Planning and Land Consolidation, Slovak University of Agriculture in Nitra, Slovakia

${ }^{5}$ Research Centre for Spatial and Organizational Dynamics, University of Algarve, Portugal

Corresponding author's e-mail: lenka.lackoova@gmail.com; fuska.jakub@gmail.com

Received: 2016.09 .30

Accepted: 2016.10.23

Published: 2017.01.01

\begin{abstract}
The main goal of this work was to verify the historic data of historic artificial water reservoir Ottergrund, Banská Štiavnica district, which is inscribed in the UNESCO world heritage list. Main focus was set to area-storage capacity curve. There is historic map with the display of reservoir bottom contours and area-storage capacity curve in a paper format. These data were analysed and compared with the results of the calculation of area-storage capacity curve that was performed with the use of a new tool with named "ASC_Curve", which is based on Python script. This tool utilizes ArcPy site package and it works with the TIN model of water reservoir bottom. In case of water reservoir Ottergrund we created the TIN model of the historic bottom; input data for the TIN model creation was the historic contour plan. The results of the analysis have shown that the storage capacity calculated with the use of the developed ASC_Curve tool is $97 \%$ of the volume mentioned in the historic map. Analysis has also show the minor mathematical errors in the calculations of the area-storage capacity data in historic contour plan. This tool can also be used also for the analysis of the current storage capacity conditions of the water reservoirs, if the surveying with echosounding equipment is performed to obtain the data to produce the TIN model of the water reservoir bottom.
\end{abstract}

Keywords: area-storage capacity curve, historic map, TIN model, water reservoir

\section{INTRODUCTION}

Erosion processes that occur in the watershed are causing the siltation of water reservoir [Halaj et al., 2013]. Changes of the reservoir bottom morphology can be caused also by processes of shoreline erosion [Pelikán and Šlezingr, 2015]. Processes of the accumulation of the sediment cause the variety of negative effects; such as loss of the reservoir storage capacity due to siltation and affecting of the biota and ecological water quality [Ahmed and Sanchez 2011, Pradhan et al. 2011, Jurík et al. 2015]. However, pollution caused by various human activities is far more dangerous to the environment [Policht-Latawiec et al., 2015] as the sediments are ultimate source of potential chemical and biological pollutants. [Apitz et al., 2005]. The processes of the water 
reservoir siltation causes worldwide the annual loss of the reservoir storage capacity in the range of $0.5-1 \%$ of the total storage capacity [White, 2010]. This process can lead to the disappearing of the particular lakes [Choiński and Ptak, 2009]. Water reservoirs belong to surface waters that are the primary water source [Tárnik and Igaz, 2015] and they are strongly affected (water quality and quantity) by the activities in the reservoir catchment area [Kaletová et al. 2013].

Analysis of the water reservoir water volume is necessary for the various purposes, such as storage capacity or fish density [Cross and Moore, 2014]. Total water volume can be calculated with different methods, such as calculation with the use of raster DEM of the reservoir bottom [Kress et al., 2005], calculation of the storage capacity change can be also performed as the comparison of two raster elevation models [Ceylan et al., 2005].

Water storage capacity and water surface area of reservoir is the function of the water level elevation, this function is described by „Area and capacity curve" [U. S. Department of the Interior, 1987] or „Area-storage capacity curve“ [Issa et al., 2015] or „Elevation-area and elevation-capacity curves" [U.S. Department of the Interior, 2001], In Slovakia, the name "bathygraphic curve" is used [Jurík et al., 2011]. This curve describes the water surface area and amount (volume) of water at the given water level elevation in the form of graph or table.

Water surface area is calculated as the surface of the contour with the examined elevation (planimetry, GIS or CAD solution). Water volume is usually calculated as the sum of partial volumes (Eq. 1) calculated between two contours with the use of the prismatic method as the multiplication of the contour elevation difference and average area of the contours (top and bottom contour of the examined partial water volume) (Eq. 2) [Jurík et al., 2011].

$$
\begin{gathered}
V_{n, \text { total }}=\sum_{n=1}^{i} V_{n, \text { partial }}\left[\mathrm{m}^{3}\right] \\
V_{n, \text { partial }}=\frac{S_{n-1}+S_{n}}{2} \Delta H=S_{\text {average }} \Delta H\left[\mathrm{~m}^{3}\right]
\end{gathered}
$$

where: $V_{n, \text { total }}-$ total water volume at the given water level, $\mathrm{m}^{3}$;

$V_{n, \text { partial }}$ - partial volume of the n-th part of water volume, $\mathrm{m}^{3}$;

$S_{n-1}$ - surface area of the previous contour, $\mathrm{m}^{2}$;
$S_{n}$ - surface area of the examined contour, $\mathrm{m}^{2}$;

$\Delta H$ - elevation difference of the contours, $\mathrm{m}$.

\section{MATERIALS AND METHODS}

\section{Study site}

Historic water reservoir Ottergrund is located in the cadaster of Banská Štiavnica town, Slovakia (Figure 1). This reservoir was enlisted in UNESCO world heritage list as the technical monuments in the mining area named "Historic Town of Banská Štiavnica and the Technical Monuments in its Vicinity" in 1993. In the past the reservoir was used as the source of water for the purposes of mining and as a drinking water supply. Dam crest elevation is $800.5 \mathrm{~m}$ above sea level (m ASL) and it is the water reservoir located at the highest elevation in the Štiavnicke Vrchy area (Hydroconsult, 1991).

\section{Input data}

Historic contour map (Figure 2) and areastorage capacity curve was used as input data for the TIN model creation and further analysis. This map was created in the year 1889 and it is drawn at the milimetre paper [Kamenár, 1889].

\section{Vectorization of the historic map}

Historic map was scanned with 600 DPI resolution in TIFF format. Afterwards the particular contours with the semi-automatic vectorization in R2V Software (R2V User's Manual, 2008) were converted from raster format (TIFF of the map) to vector format (shapefile) and the elevation from the historic map was added to each contour. Vector contour map was registered to the Slovak national coordinate system S-JTSK Křovák East-North, registration of the contour plan was performed in ArcMAP 10.2 with the ortophotomap of the location - ESRI ArcGIS reference cartographic base map and Basic topographic map of Slovak republic in scale 1:10 000 from WMS server (www. sazp.sk). Registration was performed with the use of the suitable points that were available to identify at historic map and ortophotomap - position of the building of outlet structure, spillway channel and dam crest. 


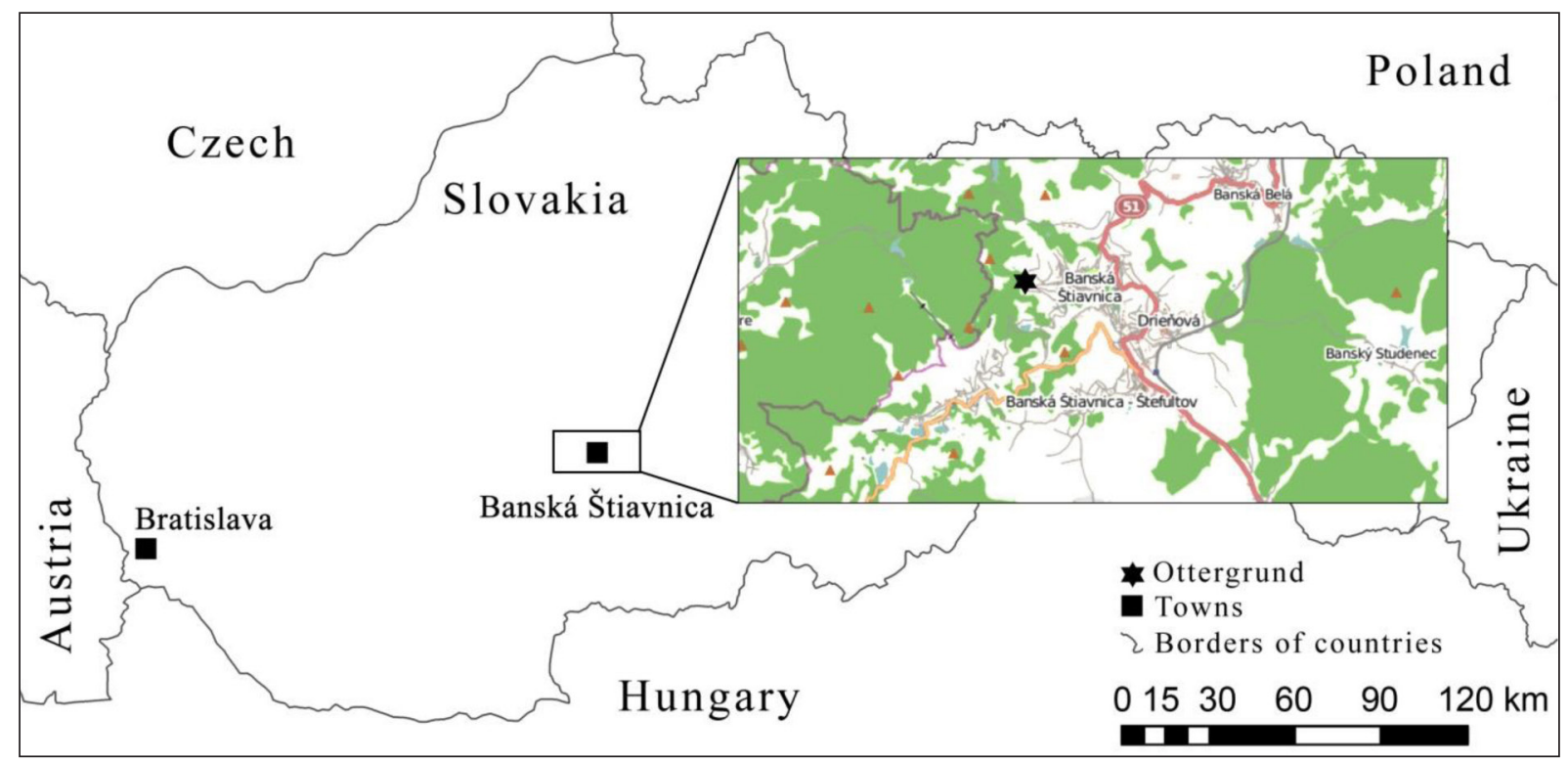

Figure 1. Location of the water reservoir Ottergrund

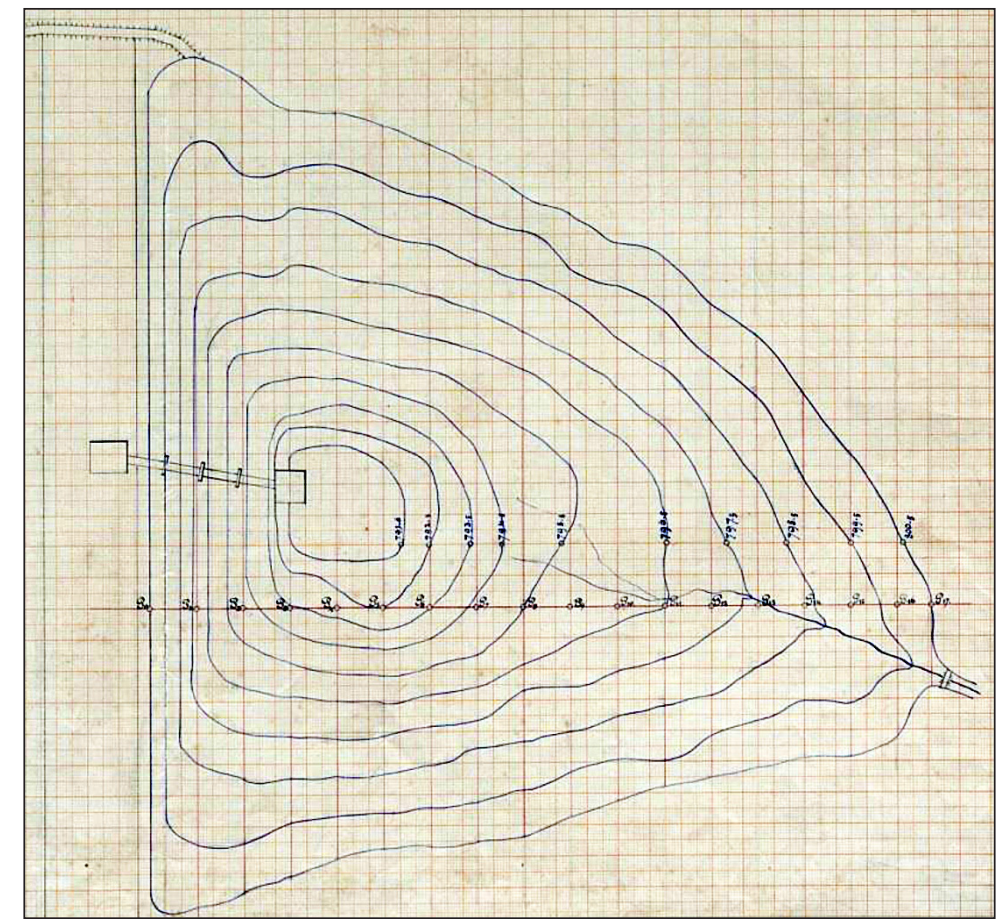

Figure 2. Historic contour map with the area-storage capacity curve in the table format

In case of water reservoir Ottergrund the historic map also contained the table of the area-storage capacity curve (ASC) without graph. Analysis of the data in the ASC table has shown minor mathematical errors in calculation of partial volumes, so it was recalculated in MS Excel in accordance to equation (1) and (2).

Verification of the data was performed with the use of TIN model of the reservoir bottom created from the input data - nodes of the vectorised contours from historic map, boundary of model was set as the contour with largest elevation $800.5 \mathrm{~m}$ ASL - maximum elevation of the water level in this reservoir. The TIN model was created with constraining of the Delaunay triangulation. This TIN model was afterwards analysed with the goal to create the ASC in table and graph format. For these purposes we created the tool with name "ASC_Curve" - stand-alone Python script that utilizes the ArcPy site package for the analysis of the TIN model to calculate the area and volume of water at demanded el- 
evations and storing the data in plain text file for further processing in MS Excel (Figure 3). ArcPy is a Python site package that provides a useful and productive way to perform geographic data analysis, data conversion, data management, and map automation with Python. ArcPy provides access to geoprocessing tools as well as additional functions, classes, and modules that allow user to create simple or complex workflows. ArcGIS applications and scripts written using ArcPy benefit from being able to access and work with the numerous Python modules developed by GIS professionals and programmers from many different disciplines [pro.arcgis.com].

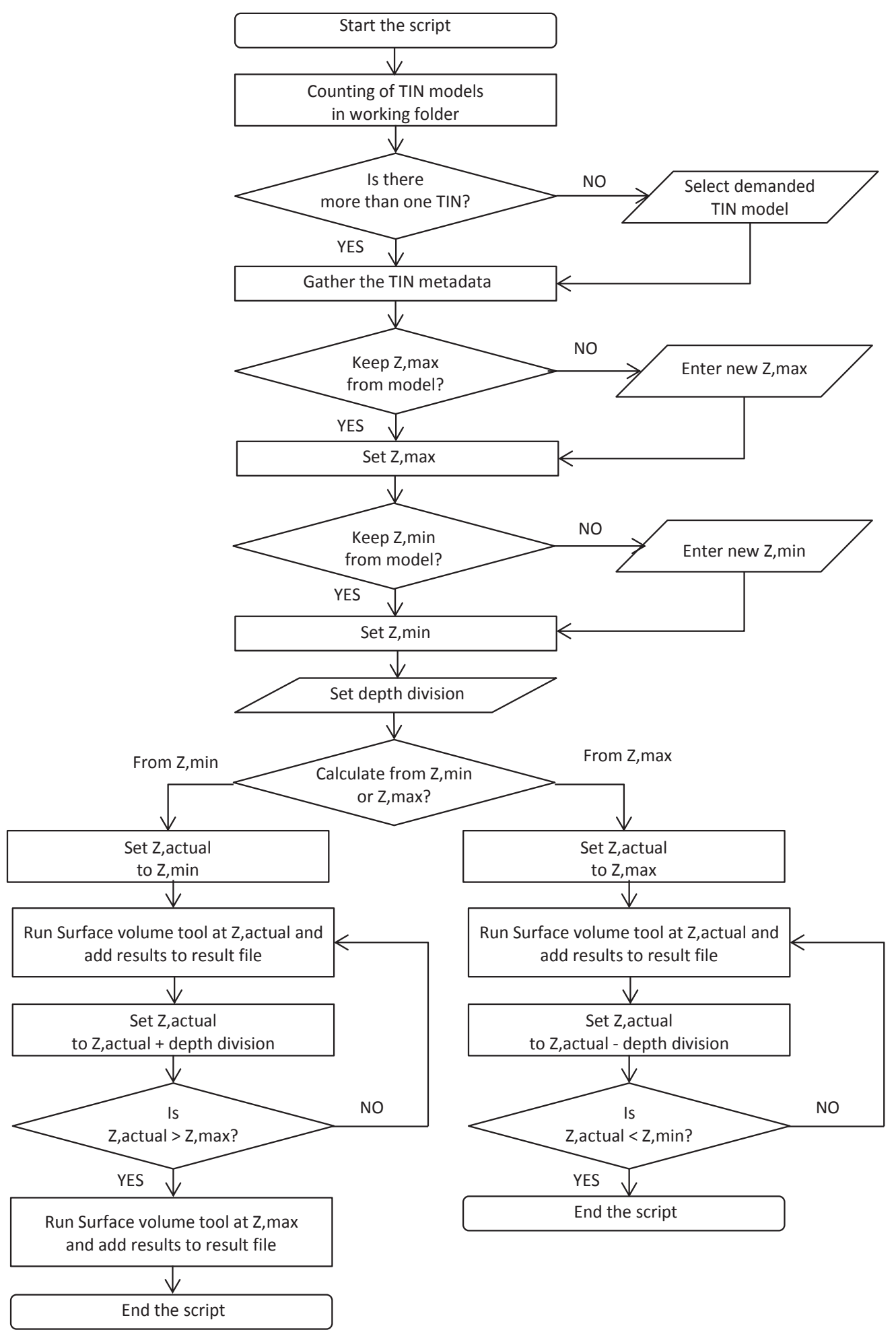

Figure 3. Flow chart of ASC_Curve Python script for the calculation of the bathygraphic curves 
"ASC_Curve" script is developed to be stored and run from the folder containing the TIN model (or more models). ASC_Curve automatically gathers minimum and maximum elevation from TIN model, path to the folder and name of the analysed TIN model. Afterwards the user can set the boundary elevations (minimum and maximum) and the interval of the water depth division - elevation difference for analysis of the reservoir. ASC_Curve allows the user to set the option of the calculation direction (from the top to the bottom or from bottom to the top). This option is to offer the solving of two main types of its further use:

1. Analysis will be performed for the identical water depths with increasing tendency (from minimal elevation of TIN in direction to the top) - in this case the ASC_Curve can analyse the TIN model and offer the results for the demanded water depths - that means the ASC_Curve will analyse the water volume and water surface area in accordance to the water depths (Fig. 4a)

2. Analysis will be performed for the identical water level elevations with decreasing tendency (from maximal elevation of TIN in direction to the bottom) - in this case the ASC_Curve can analyse the TIN model and offer the results for the demanded water level elevations. This option is important for the comparative studies of different time stages that are demanded to answer the question of the storage capacity and water surface area development at the same water level elevations in both time stages (Figure 4b).

\section{RESULTS AND DISCUSSION}

Historic map of water reservoir Ottergrund displays the shape of the water reservoir bottom as ten contours with the elevation from 791.6 to $800.5 \mathrm{~m}$ ASL - elevation difference is $1.0 \mathrm{~m}$ from the contour $792.5 \mathrm{~m}$ ASL. ASC table contains the partial and total volumes for the particular contour elevations, but there is one uncertain elevation - maximum contour elevation is $800 \times 500 \mathrm{~m}$ ASL, but in the ASC table is the calculation up to $800 \times 542 \mathrm{~m}$ ASL. After the checking of the map and available documentation we did not find the explanation for this data and the meaning of 42 is not clear.

In accordance to the calculated parameters of ASC in historic map we calculated the parameters with the ASC_Curve tool for the same elevations 791.6-800.5 m ASL with the elevation difference of 1 meter with the calculation from the highest elevation to lowest. The results were processed in MS Excel in table (Table 1) and graph format (Figure 6).

Result of the ASC_Curve analysis was significantly different from the volume data in the ASC table in historic map (Table 2). These differences were also achieved in the surface area

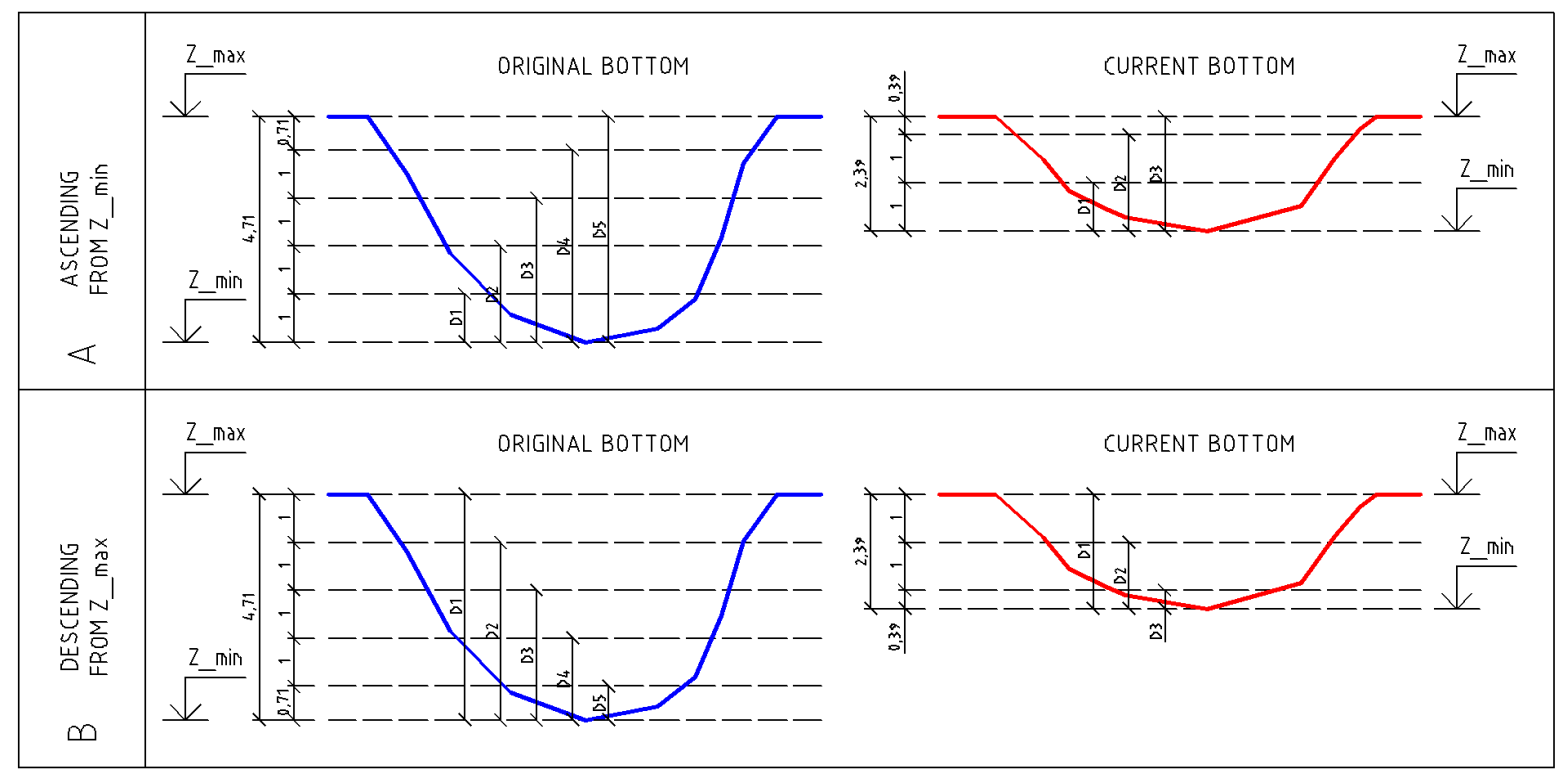

Figure 4. Direction of the ASC_Curve script calculation: a. from lowest elevation to provide whole numbers of the water depths; b. from highest elevation to provide equal elevation of the water levels for comparison of original (historical) and current status of 
Table 1. Parameters of bathygraphic curves from historic map and from the analysis of TIN models

\begin{tabular}{|c|c|c|c|c|c|c|c|c|c|}
\hline \multirow{3}{*}{$\begin{array}{l}\text { Water level } \\
\text { elevation } \\
\text { [m ASL] }\end{array}$} & \multicolumn{5}{|c|}{ Historic data } & \multirow{2}{*}{\multicolumn{2}{|c|}{$\begin{array}{l}\text { Data from TIN model } \\
\text { (ortophotomap } \\
\text { referenced) }\end{array}$}} & \multirow{2}{*}{\multicolumn{2}{|c|}{$\begin{array}{l}\text { Data from TIN model } \\
\text { (millimeter paper } \\
\text { referenced) }\end{array}$}} \\
\hline & \multirow{2}{*}{$\begin{array}{l}\text { Water level } \\
\text { area } \\
{\left[\mathrm{m}^{2}\right]}\end{array}$} & \multicolumn{2}{|c|}{$\begin{array}{c}\text { Volume data } \\
\text { from table in map }\end{array}$} & \multicolumn{2}{|c|}{$\begin{array}{l}\text { Recalculated volume } \\
\text { (prismatic method) }\end{array}$} & & & & \\
\hline & & $\begin{array}{c}\text { Partial } \\
\text { volume } \\
{\left[\mathrm{m}^{3}\right]}\end{array}$ & $\begin{array}{c}\text { Total } \\
\text { volume } \\
{\left[\mathrm{m}^{3}\right]}\end{array}$ & $\begin{array}{c}\text { Partial } \\
\text { volume } \\
{\left[\mathrm{m}^{3}\right]}\end{array}$ & $\begin{array}{c}\text { Total } \\
\text { volume } \\
{\left[\mathrm{m}^{3}\right]}\end{array}$ & $\begin{array}{c}\text { Water level } \\
\text { area } \\
{\left[\mathrm{m}^{2}\right]}\end{array}$ & $\begin{array}{c}\text { Total } \\
\text { volume } \\
{\left[\mathrm{m}^{3}\right]}\end{array}$ & $\begin{array}{c}\text { Water } \\
\text { level area } \\
{\left[\mathrm{m}^{2}\right]}\end{array}$ & $\begin{array}{c}\text { Total } \\
\text { volume } \\
{\left[\mathrm{m}^{3}\right]}\end{array}$ \\
\hline 791.6 & 54.3 & 0 & 0 & 0 & 0 & 41.1 & 0.0 & 48.6 & 0.0 \\
\hline 792.5 & 94.1 & 66.7 & 66.7 & 74.2 & 74.2 & 81.6 & 53.9 & 95.9 & 63.6 \\
\hline 793.5 & 147.7 & 120.9 & 187.6 & 120.9 & 195.1 & 130.6 & 159.3 & 152.6 & 186.9 \\
\hline 794.5 & 237.3 & 192.5 & 380.1 & 192.5 & 387.6 & 202.2 & 324.3 & 237.6 & 380.4 \\
\hline 795.5 & 377.8 & 307.5 & 687.6 & 307.6 & 695.2 & 322.9 & 583.7 & 379.1 & 684.8 \\
\hline 796.5 & 587.9 & 482.8 & 1170.4 & 482.9 & 1178.0 & 502.7 & 992.1 & 591.4 & 1164.2 \\
\hline 797.5 & 813.2 & 700.5 & 1870.9 & 700.6 & 1878.6 & 700.4 & 1591.4 & 822.9 & 1868.4 \\
\hline 798.5 & 1113.4 & 963.3 & 2834.2 & 963.3 & 2841.9 & 953.6 & 2414.9 & 1121.3 & 2836.4 \\
\hline 799.5 & 1475.9 & 1294.6 & 4128.8 & 1294.7 & 4136.5 & 1256.8 & 3515.8 & 1480.6 & 4131.8 \\
\hline 800.5 & 1887.9 & 1681.9 & 5810.7 & 1681.9 & 5818.4 & 1607.8 & 4949.3 & 1893.8 & 5820.0 \\
\hline
\end{tabular}

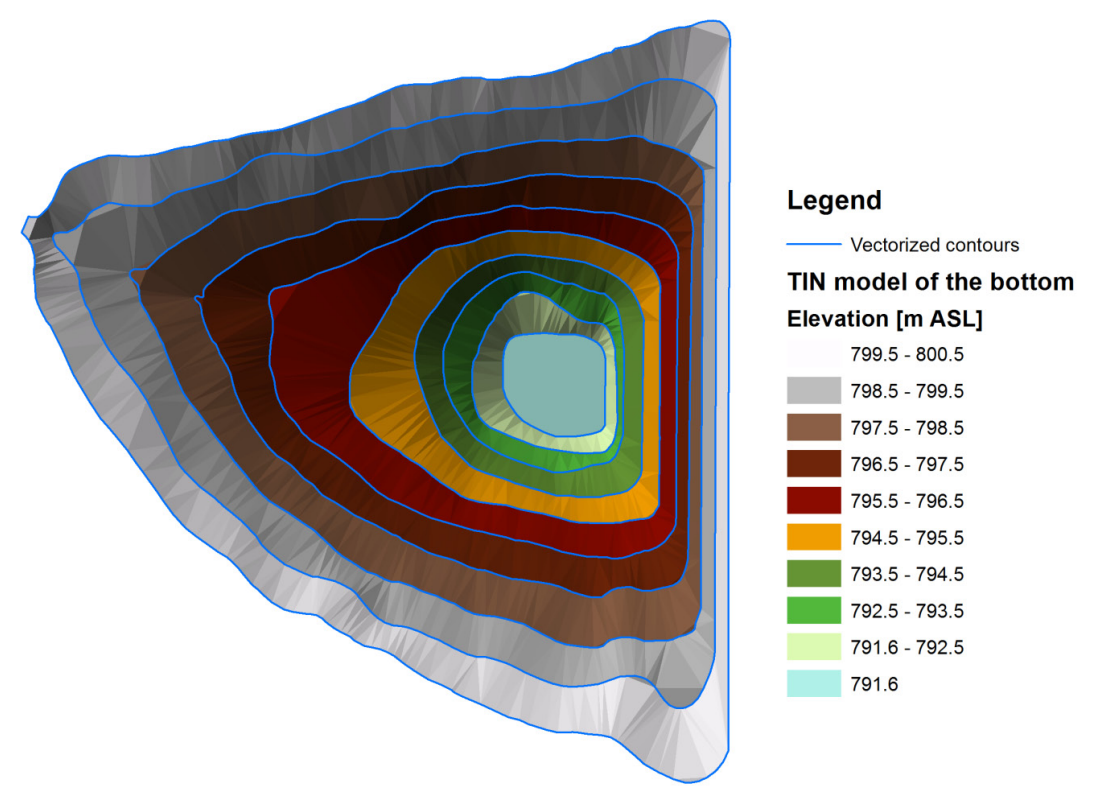

Figure 5. Reconstructed contour map of Ottergrund bottom

data calculation - this led us to conclusion that the georeferencing of historic map raster (Fig. 2) was not proper and that led to the distortion of the raster input - this distortion resulted in deformation of the vectorised contours. To eliminate this error we performed the new georeferencing with the different approach. We used the grid of the millimetre paper $-1 \mathrm{~cm}$ raster represents 2 $\mathrm{m}$ (scale 1:500). We recreated the point grid field with distance of points $2 \times 2 \mathrm{~m}$ in the ArcMAP 10.2 and the scanned map was georeferenced to these points with the use of millimetre paper grid nodes. Afterwards we shifted and rotated the referenced map to fit the visually identical points at the ortophotomap (dam, buildings at the shoreline). This newly referenced map was afterwards vectorised manually in ArcMAP 10.2 and the TIN model of the Otergrund water reservoir was created (Fig. 5).

Then the ASC_Curve tool was used again to process the TIN model to obtain the water surface area and water storage capacity (Table 1 and 2).

In accordance to the results of the analysis of the second referencing we can state that the analysis of the ASC_Curve tool resulted in average to $3 \%$ smaller water volumes, compared to the conventional prismatic method of the calculation of the area-storage capacity. This result makes the newly developed ASC_Curve tool available and useful tool for the area-storage capacity curve calculations of the current status. TIN model created from spatially referenced depth-point hy- 
Table 2. Comparison of the water volume from historic map and from the analysis of TIN models

\begin{tabular}{|c|c|c|c|c|c|}
\hline \multirow{3}{*}{$\begin{array}{l}\text { Water level } \\
\text { elevation } \\
\text { [m ASL] }\end{array}$} & \multicolumn{5}{|c|}{ Water volume } \\
\hline & \multirow{2}{*}{$\begin{array}{c}\text { Original } \\
\text { historic data }\left[\mathrm{m}^{3}\right] \\
\text { Recalculated historic } \\
\text { data }\left[\mathrm{m}^{3}\right]\end{array}$} & \multirow{2}{*}{$\begin{array}{l}\text { OPM } \\
\text { referenced }\left[\mathrm{m}^{3}\right]\end{array}$} & \multirow{2}{*}{$\begin{array}{l}\text { MMP } \\
\text { referenced }\left[\mathrm{m}^{3}\right]\end{array}$} & $\begin{array}{l}\text { OPM } \\
\text { referenced }\end{array}$ & $\begin{array}{l}\text { MMP } \\
\text { referenced }\end{array}$ \\
\hline & & & & \multicolumn{2}{|c|}{$\begin{array}{c}\% \text { of original historic data } \\
\% \text { of recalculated historic data }\end{array}$} \\
\hline \multirow{2}{*}{791.6} & 0 & \multirow{2}{*}{0} & \multirow{2}{*}{0} & - & - \\
\hline & 0 & & & - & - \\
\hline \multirow{2}{*}{792.5} & 66.7 & \multirow{2}{*}{53.9} & \multirow{2}{*}{63.6} & 80.7 & 95.4 \\
\hline & 74.2 & & & 72.6 & 85.7 \\
\hline \multirow{2}{*}{793.5} & 187.6 & \multirow{2}{*}{159.3} & \multirow{2}{*}{186.9} & 84.9 & 99.6 \\
\hline & 195.1 & & & 81.7 & 95.8 \\
\hline \multirow{2}{*}{794.5} & 380.1 & \multirow{2}{*}{324.3} & \multirow{2}{*}{380.4} & 85.3 & 100.1 \\
\hline & 387.6 & & & 83.7 & 98.1 \\
\hline \multirow{2}{*}{795.5} & 687.6 & \multirow{2}{*}{583.7} & \multirow{2}{*}{684.8} & 84.9 & 99.6 \\
\hline & 695.2 & & & 84.0 & 98.5 \\
\hline \multirow{2}{*}{796.5} & 1170.4 & \multirow{2}{*}{992.1} & \multirow{2}{*}{1164.2} & 84.8 & 99.5 \\
\hline & 1178.0 & & & 84.2 & 98.8 \\
\hline \multirow{2}{*}{797.5} & 1870.9 & \multirow{2}{*}{1591.4} & \multirow{2}{*}{1868.4} & 85.1 & 99.9 \\
\hline & 1878.6 & & & 84.7 & 99.5 \\
\hline \multirow{2}{*}{798.5} & 2834.2 & \multirow{2}{*}{2414.9} & \multirow{2}{*}{2836.4} & 85.2 & 100.1 \\
\hline & 2841.9 & & & 85.0 & 99.8 \\
\hline \multirow{2}{*}{799.5} & 4128.8 & \multirow{2}{*}{3515.8} & \multirow{2}{*}{4131.8} & 85.2 & 100.1 \\
\hline & 4136.5 & & & 85.0 & 99.9 \\
\hline \multirow{2}{*}{800.5} & 5810.7 & 10193 & 58200 & 85.2 & 100.2 \\
\hline & 5818.4 & 4949.3 & $50<0.0$ & 85.1 & 100.0 \\
\hline & & & & 84.6 & 99.4 \\
\hline Average for & elevations: & & & 82.9 & 97.4 \\
\hline
\end{tabular}

Note: OPM - orthophotomap; MMP - millimetre paper

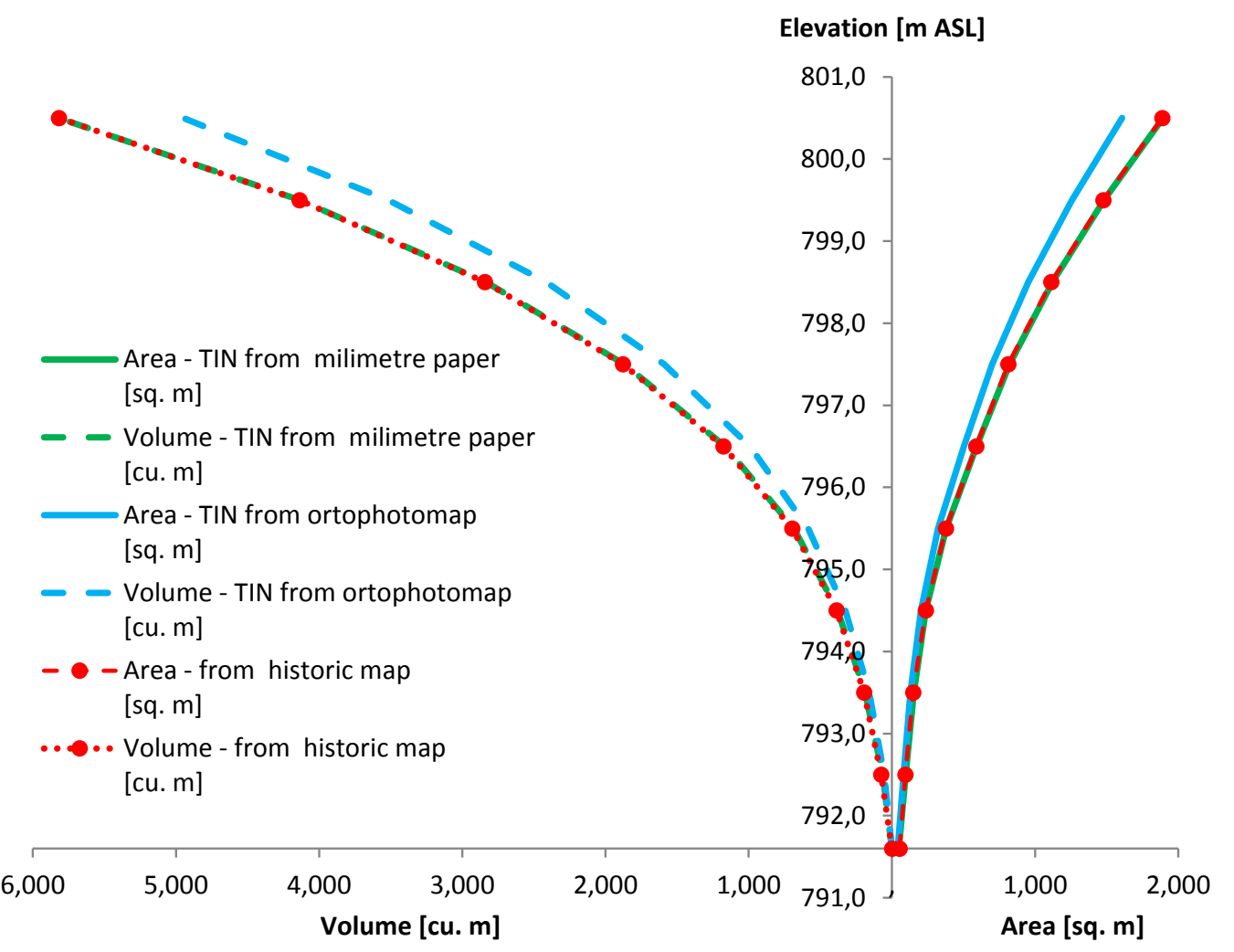

Figure 6. Area-storage capacity curves of the water reservoir Ottergrund 
droacoustic surveying can be used for the calculations of the current water volume [Byrnes et al. 2002, USACE 2013, Fuska 2015].

This tool was developed by J. Fuska, D. Kubinský and $\mathrm{K}$. Weis and it is free to download at the link http://bit.ly/1Oxbnfi, original link is http://www.dkubinsky.sk/blog/veda-a-vyskum/ automaticky-vypocet-plochy-a-objemu-vyvojnastroja-na-baze-python-skriptu-pre-arcgis.

This script can be used by the non-governmental, academic or commercial experts, but it is necessary to remember that developers do not take any responsibilities for the errors or damages caused by the use of this script. We do not guarantee the functionality and the use of this script is on the own responsibility and risk of the user.

\section{CONCLUSIONS}

Assessment of the water reservoir Ottergrund storage capacity and water surface area performed with this study has shown the multiple aspects of this type of analysis. It is necessary to consider the quality of the input historic data due to possible deformations of physical historical paper maps - shrinkage caused by temperature or air humidity the longer time as the map is more than 100 years old and the quality of the mathematical processing, but there is also the need of the quality of the georeferencing as it may bring the distortion of the input data that will certainly affect the quality of the analysis outputs.

Area-storage capacity curve parameters can be easily calculated from the input TIN model in the ArcMAP 10.2 software with the use of newly developed tool ASC_Curve that was created as the Python script. This tool offers fast and easy way of the area-storage capacity curve parameters calculation in comparison to the conventional prismatic method of the calculation - in case of the analysis of the Ottergrund water reservoir the ASC_Curve analysis calculated the water storage capacity only $3 \%$ smaller than water storage capacity calculated with conventional prismatic method calculation.

Area-storage capacity curve can be used for the assessment of the historic data, but there is a large potential mainly in the field of regular or current assessment of the storage capacity of the particular water reservoirs. Current research of water reservoirs worldwide is based on the use of echosounding equipment to provide digital eleva- tion models such as the TIN model of the current reservoir bottom. With the use of the developed ASC_Curve tool the development of the storage capacity and water volume can be easily calculated for the purpose of irrigation, fish production and drinking or industrial water supply. As the morphology of the water reservoir is strongly affected by siltation with the material eroded and transported from the reservoir watershed, this tool can answer the question of the total amount of the material eroded and transported with the surface runoff to the water reservoir.

\section{Acknowledgements}

This study was supported with the following grants and projects:

- APVV-15-0562: Effective irrigation management as a device of changing climate,

- APVV SK-PT-2015-0005: Establishing new scientific and research networking in the field of water reservoir storage capacity monitoring addressing the issue of climate change,

- VEGA 1/0456/14: Management of the Soil Moisture Regime as a Tool for Climate Change Adaptation,

- VEGA 2/0050/14: The impact of biological soil crust and microtopography on infiltration and flow of water in sandy soil.

\section{REFERENCES}

1. Ahmed K. B., Sanchez M. 2011. A study of the factors and processes involved in the sedimentation of Tarbela reservoir, Pakistan. Environmental Earth Sciences, 62, 927-933.

2. Apitz S.E., Brils J., Marcomini A., Critto A., Agostini P., Micheletti Ch., Pippa R., Scanferla P., Zuin S., Lánczos T., Dercová K., Kočan A., Petrík J. Hucko P., Kušnír P. 2005. Approaches and frameworks for managing contamined sediments - a European perspective. Assessment and Remediation of Contaminated Sediments. Proceedings of the NATO Advanced Research Workshop on Assessment and Remediation of Contaminated Sediments, Bratislava, Slovak Republic, 18-21 May 2005, 5-83.

3. Byrnes M.T., Baker J.L., Li F. 2002. Quantifying potential measurement errors and uncertainties associated with bathymetric change analysis. US Army Corps of Engineers Report ERDC/CHL CHETN-IV-50.

4. Ceylan A., Karabork H., Ekozoglu I. 2011. An analysis of bathymetric changes in Altinapa reser- 
voir. Carpathian Journal of Earth and Environmental Sciences, 6(2), 15--24.

5. Cross B.K, B.C. Moore. 2014. Lake and reservoir volume: hydroacoustic survey resolution and accuracy. Lake and Reservoir Management 30. http:// www.tandfonline.com/doi/full/10.1080/10402381. 2014.960115

6. Fuska J., Bárek V. 2015. Surveying of small water reservoirs for water management purposes. Lecture Notes in Geoinformation and Cartography - Surface models for geosciences, 99-111.

7. Halaj P., Bárek V., Halajová D., Báreková A., Stred'anský J., Šinka Z. 2013. Effect of catchment land use on hydromorphological status of streams in agricultural land. In: Water resources. Forest, marine and ocean ecosystems. Sofia: STEP92 Technology.

8. Hydroconsult 1991. Banskoštiavnická oblast' štúdia, Bratislava. The evaluation of soil water storage in a small catchment in 2009 and 2010.

9. Choiński A., Ptak M. 2009. Lake Infill as the Main Factor Leading to Lake's Disappearance. Polish Journal of Environmental Studies, 18, 3, 347--352.

10. Issa I.E., Al-Ansari N.A., Knutsson S. 2015. Area-Storage Capacity curves for Mosul Dam, Iraq Using Empiricaland Semi-Empirical Approaches. Hydropower, 15.

11. Jurík L', Pierzgalski E., Hubačíková V. 2011. Vodné stavby v krajine. Malé vodné nádrže. Slovak University of Agriculture, Nitra.

12. Jurik L', Húska D., Halászová K., Bandlerová A. 2015. Small water reservoirs - sources of water or problems? Journal of Ecological Engineering, 16(4), 22-28.

13. Kaletová T., Mandalová K, Stradiot P. 2013 Evaluation of sustainable development with recpect to land use and water quality in the Poprad catchment. Acta Hydrologica Slovaca, 14(2), 437-445.

14. Kamenár J. 1889. Ottergrundi-tó köbörésé. Historic paper map of the Ottergrund water reservoir.

15. Kress W.H., Sebree S.K., Littin G.R., Drain M.A., Kling M.E. 2005. Comparison of preconstruction and 2003 bathymetric and topographic surveys of Lake McConaughy, Nebraska. U.S. Geological
Survey Scientific Investigations Report 20055040. Nebraska (The Central Nebraska Public Power and Irrigation District).

16. Pelikán P., Šlezingr M. 2015. Parameters of wind driven waves on Nove Mlyny water reservoir. In: Water Management and Hydraulic Engineering 2015. 1. edition. Brno: Institute of Water Structures, FCE, BUT, 55-64.

17. Policht-Latawiec A., Bogdal A., Kanownik W., Kowalik T., Ostrowski K. 2015. Variability of physicochemical properties of water of the transboundary Poprad river. Journal of Ecological Engineering, 16(1), 100-109. DOI: 10.12911/22998993/593.

18. Pradhan D., Ancev, T., Drynan R., Harris M. 2011. Management of water reservoirs (Embungs) in West Timor, Indonesia. Water Resources Management, 25, 339-356.

19. www.pro.arcgis.com. What is ArcPy? [Online at 3. August 2016] http://pro.arcgis.com/en/pro-app/ arcpy/get-started/what-is-arcpy-.htm

20. R2V User's Manual. 2008. Advanced Raster to Vector Conversion Software. http://www.ablesw. com/r2v/R2Vmanual.pdf (Online: 6.04.2016).

21. Tárnik A., Igaz D. 2015. Quantification of soil water storage available to plants in the Nitra river basin. Acta Scientiarum Polonorum, 14(2), 209-216.

22. U.S. Department of the Interior, 1987. Design of small dams. A Water Resources Technical Publication. Third Edition.

23. U.S. Department of the Interior, 2001. Procedural Documentation and Accuracy Assessment of Bathymetric Maps and Area/Capacity Tables for Small Reservoirs.

24. USACE (United States Army Corps of Engineers). 2013. Engineering and design: hydrographic surveying. Report EM 1110-2-1003, Washington, D.C.

25. White W.R. 2010. World water: resources, usage and the role of man--made reservoirs. Buckinghamshire: Foundation for Water research. http:// www.fwr.org/wwtrstrg.pdf (Online: 20.09.2015).

26. www.sazp.sk. Basic topographic maps 1:10000. WMS server. http://nipi.sazp.sk/arcgis/services/ podklady/zbgis10r/MapServer/WMSServer/? 